\title{
Mapping Ground Water Potential Recharge Zones in Parts of Akwa Ibom State Using Geographic Information System (G.I.S)
}

\author{
Thomas Harry ${ }^{1}$ Ekpedeme Asuaiko ${ }^{1}$ Nsidibe Akata $^{2}$ Ndifreke Akpan ${ }^{1}$ \\ 1. Department of Geology, Akwa Ibom State University, Ikot Akpaden, AKS \\ 2. Diviem Nigeria Ltd, Victoria Island, Lagos Nigeria
}

\begin{abstract}
The study was conducted to map ground water potential recharge zones based on physical parameters in southern parts of Akwa Ibom State using Geographical information system (GIS). The aim was to produce ground water recharge potential map for the protection of water quality and the management of ground water systems. Thematic maps of lithology, land cover/ land use, lineaments, drainage, and slope of the study area were produced from various sources. The influence of each factors to groundwater recharge and interaction between the factors were examined and ranks were assigned. Weighting values were assigned according to the degree of the Multiple Influencing Factors (MIF). All the thematic maps or layers were integrated applying weighted overlay analysis in a GIS environment (Arc Map 10.5 software) to produce the resultant map. The study produced a ground water recharge potential map of parts of Akwa Ibom State. The resultant map indicated that the most effective groundwater recharge potential zone was trending in the NW - SE direction. In this region, the coastal plain sands of the Benin Formation, the agricultural land and forest possesses high infiltration ability. Additionally, the concentration of drainage also indicates the ability of stream-flow to recharge the groundwater system. The downstream region is least effective for groundwater recharge, mainly due to its elevation being as low as sea level.
\end{abstract}

Keywords: Mapping, Groundwater, GIS, Lineament, Drainage, Recharge

DOI: $10.7176 / \mathrm{CER} / 12-2-08$

Publication date: February $29^{\text {th }} 2020$

\section{Introduction}

Groundwater recharge is the movement of water from the unsaturated zone into the saturated zone below the water table surface, together with the associated flow away from the water table within the saturated zone (Freeze and Cherry 1979). It is the volume of water that reaches the saturated zone of the aquifer contributing to the replenishing ground water reservoir. It is an extremely important water component of the circulation cycle in nature. Ground water recharge could be a natural or an artificial process. The natural recharge occurs from direct infiltration of rainfall or from the percolation of adjacent water bodies, and the artificial recharge when it is induced by human activity such as irrigation, urbanization, and construction of injection boreholes or river spreading (Martin 2012). Akintola (1974) classified ground water recharge into actual recharge and potential recharge depending on the infiltrated water that reaches the water table from the recharge, estimated from surface water and unsaturated zone which may reach the water table (actual) and which may not reach the water table (potential).

Many factors affect the occurrence and movement of groundwater as it is not uniformly distributed in terms of quantity and quality. Depending on the hydrogeological and climatic conditions, either the magnitude of natural groundwater resources or hydraulic parameters of rocks represent the limit of groundwater development (Krasny, 1997; Martin, 2012). Furthermore, in a basin where average annual rainfall is above $1000 \mathrm{~mm}$, groundwater potential would be a function of secondary porosity (Sener et al., 2005; Sander, 2007), vegetation (Akintola, 1974; Shaban et al., 2006), surface drainage (Sener, et al., 2005; Jha et al., 2007; Sander, 2007) and lithology (Jha et al., 2007; Yeh et al., 2008). Lithology affects the groundwater recharge by controlling the percolation of water flow (El-Baz and Himida 1995). Shaban et al. (2006) observed that the type of rock exposed to the surface significantly affects groundwater recharge. Land use/cover is an important factor in groundwater recharge. Biological decomposition of the roots helps loosen the rock and soil, so that water can percolate to the surface of the earth easily. Vegetation prevents direct evaporation of water from soil. The roots of a plant can absorb water, thus preventing water loss. Leduc et al. (2001) estimated the difference in the amount of groundwater recharge due to changes of land utilization and vegetation from changes in the groundwater level. Lineament is another factor that affects ground water recharge. Lineaments are defined as the simple and complex linear properties of geological structures such as faults, cleavages, fractures, and various surfaces of discontinuity, that are arranged in a straight line or a slight curve, as detected by remote sensing are used to infer ground water movement and storage. Lattman and Parizek (1964) used lineaments to exploit groundwater. Another factor is the drainage. The drainage-length density is significantly correlated with the groundwater recharge; a zone with a high drainage-length density has a high level of groundwater recharge. Many studies have integrated lineaments and drainage maps to infer the groundwater recharge potential zone (Edet et al. 1998; Shaban et al. 2006).

Another factor in groundwater recharge is the slope. The slope gradient directly influences the infiltration of 
rainfall. Larger slopes produce a smaller recharge because water runs rapidly off the surface of a steep slope during rainfall, not having sufficient time to infiltrate the surface and recharge the saturated zone. There are several methods available to estimate natural ground water recharge. One of the methods is the use of soil physical parameters as indirect techniques of estimating potential natural ground water recharge (Edet et al. 1998). Salama et al. (1994) used aerial photos and information from a satellite to derive the lithology, topography, and geological characteristics of the Salt River in Western Australia. These properties can be used to determine the mechanism of groundwater flow and the groundwater recharge zone. Their analytical results demonstrate that the sandy plain is the major recharge zone. Edet et al. (1998) classified groundwater recharge potential zones in southeast Nigeria as high, medium, or low. They found that linear features, drainage, lithology, temperature of groundwater, vertical hydraulic conductivity, yield, and transmissivity closely control the recharge potential zones. Shaban et al. (2006) explored the recharge potential map of the Occidental Lebanon, and found that the regions of hard, fractured, and karstified limestone were excellent potential areas for groundwater recharge, while the least effective recharge potential was in high-populated areas and in relatively flat areas covered by soft materials. Information on the natural ground water potential recharge zones in Akwa Ibom State, based on soil physical parameters is grossly inadequate. Therefore the study was conducted to map ground water potential recharge zones based on soil physical parameters in parts of Akwa Ibom State using Geographic Information System (GIS) for the protection of water quality and the management of groundwater systems.

\subsection{Study area}

The study was conducted n Akwa Ibom State located in south eastern Nigeria. It lies between longitudes $07^{\circ} 30^{\prime}$, $08^{\circ} 20^{\prime} \mathrm{E}$ and latitudes $04^{\circ} 30^{\prime}, 04^{\circ} 53^{\prime} \mathrm{N}$, and underlain mainly by coastal plain sands, beach ridge sands, sandstone/shale and alluvial deposits parent materials. The climate is humid tropical, annual rainfall ranges from more than $3000 \mathrm{~mm}$ along the coast to about $2250 \mathrm{~mm}$ at the extreme north, with 1-3 dry months in a year. Mean annual temperature varies between $26^{\circ}-28^{\circ} \mathrm{C}$, while relative humidity varies between $75-80 \%$. The original natural vegetation which comprised lowland rainforest, mangrove forest and coastal vegetation, has given way to a mosaic farmland, riparian forest and oil palm forest (Petters et al., 1989).

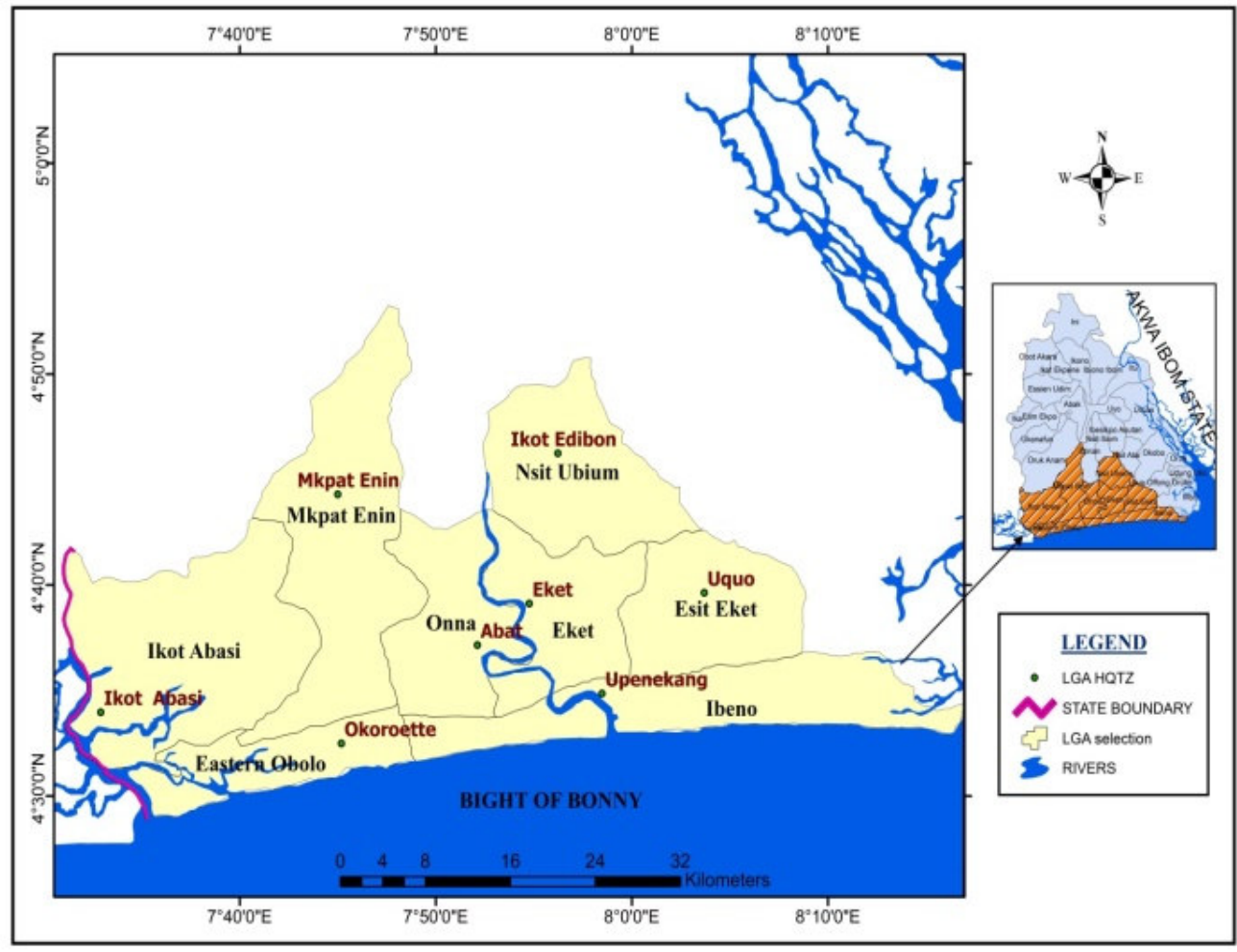

Fig.1. Map of the study area

\section{Methodology}

Since, the study involved mapping of different features that influence groundwater recharge in parts of Akwa Ibom state in different degrees. Thematic maps of Drainage, Lithology, Land use/Land cover, Slope, and Lineament of the study area were obtained from various sources for integration and analysis to get the final result using the ESRI ArcGIS 10.5 software. The lithological map of the study area was digitized from an existing vector map and classification was done using the image classification tool bar; different polygons were labeled separately and 
ranks assigned to distinct classes. The land use/ land cover map of the study area was extracted by masking and derived form a 7 band Landsat ${ }^{\mathrm{TM}}$ data derived from EARTH EXPLORER, using the image classification tool bar, signatures were selected for the image i.e. areas that are built up and vice versa were reclassified by likelihood and assigned weightage based on influence levels. The 2006 Edition of the Lineaments Map of Nigeria from the Nigerian Geological Survey Agency (N.G.S.A) was digitized and converted to lineament density using the line density tool in spatial analysis tool. This was then classified into four classes viz;- lineament present, not present, neighborhood and linear intersections.

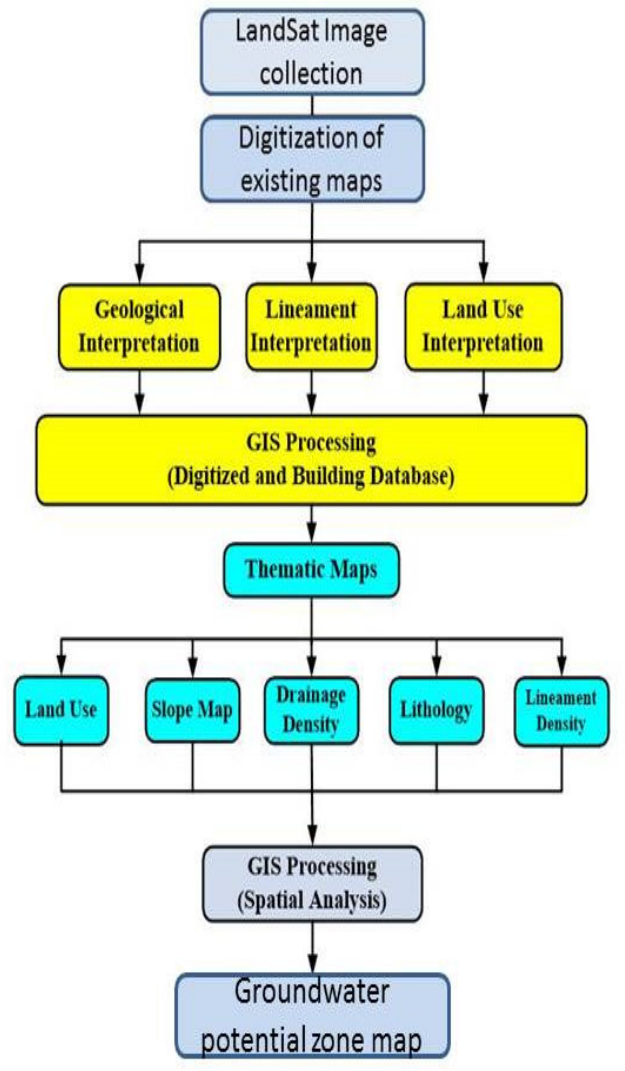

Fig.2. Methodology flowchart of the groundwater potential zone investigation.

Areas with lineament are assigned the maximum rank and without lineament with least. The slope analysis function in GIS was used to assess the variation of slope in the study area using the Digital Elevation Model (DEM) data from the Landsat ${ }^{\mathrm{TM}}$ data derived from EARTH EXPLORER. Also, the Landsat ${ }^{\mathrm{TM}}$ data obtained from EARTH EXPLORER was mosaicked and clipped to the study area. The clipped DEM was then filled, using the fill tool in spatial analysis tool to remove small imperfections in the data. To create a raster of flow direction from each cell to its steepest down slope neighbor flow direction tool was used. A raster of accumulated flow was next created using flow accumulation tool with flow direction as the input and further the drainage density map was obtained by the line density analysis tool (Harry et al, 2017; 2018).

\subsection{The Infrastructure of the Groundwater Recharge Potential Model}

The groundwater recharge potential zone has been assessed in many countries (Krishnamurthy et al. 1996; Saraf and Choudhury 1998; Shahid et al. 2000; Jaiswal et al. 2003; Sener et al. 2005; Shaban et al. 2006). However, the groundwater recharge potential zone has barely been assessed in the study area using the GIS approach. In this study, the weights of different factors for groundwater recharge potential and the score under various characteristics were assessed based on the Multiple Influencing Factor (M.I.F). The factors influencing groundwater recharge, and their relative importance, are compiled from previous literature. Duplicate factors were combined and only representative factors were extracted. This study uses lithology, land use/cover, lineaments, drainage, and slope as the five significant factors affecting groundwater recharge potential. The factors influencing groundwater recharge potential, which are listed in Table 1. 
Table 1. Factors affecting ground water recharge - classified criteria

\begin{tabular}{|l|l|}
\hline Factors & Basis for categorization \\
\hline Lithology & Rock type, weathering character, joints, fractures \\
\hline Land use / land cover & Type, areal extent and associated vegetation \\
\hline Lineaments & Lineament - density value \\
\hline Drainage & Drainage - density value \\
\hline Slope & Slope gradient \\
\hline
\end{tabular}

\subsection{Establishment of factors and preparation of thematic maps}

Lithology

Shaban et al. (2006) pointed out that the type of rock exposed to the surface significantly affects groundwater recharge. Lithology affects the groundwater recharge by controlling the percolation of water flow (El-Baz and Himida 1995). Although some investigations have ignored this factor by regarding the lineaments and drainage characters as a function of primary and secondary porosity, this study includes lithology to reduce uncertainty in determining lineaments and drainage.

The lithological map of the study area was digitized from an existing vector map and classification was done using the image classification tool bar; different polygons were labeled separately and ranks assigned to distinct classes.

\subsection{Land use/cover}

Land use/cover is an important factor in groundwater recharge. It includes the type of soil deposits, the distribution of residential areas, and vegetation cover. Shaban et al. (2006) concluded that vegetation cover benefits groundwater recharge in the following ways:

1. Biological decomposition of the roots helps loosen the rock and soil, so that water can percolate to the surface of the earth easily.

2. Vegetation prevents direct evaporation of water from soil.

3. The roots of a plant can absorb water, thus preventing water loss.

Leduc et al. (2001) estimated the difference in the amount of groundwater recharge due to changes of land utilization and vegetation from changes in the groundwater level. Land use/cover was included in this study as an important factor affecting the groundwater recharge process.

The land use/ land cover map of the study area was extracted by masking and derived form a 7 band Landsat TM data derived from EARTH EXPLORER, using the image classification tool bar, signatures were selected for the image i.e. areas that are built up and vice versa were reclassified by likelihood and assigned weightage based on influence levels.

\subsection{Lineaments}

The analysis of lineaments has been applied rigorously to explain geological status since geological images were first utilized in the 1930s. Lineaments are currently not fully defined. O'Leary et al. (1976) has defined lineaments as the simple and complex linear properties of geological structures such as faults, cleavages, fractures, and various surfaces of discontinuity, that are arranged in a straight line or a slight curve, as detected by remote sensing. Many non-geological structures, such as roads and channels, cause errors in the analysis of lineaments. Therefore, geologic maps and on-site investigations must be used to eliminate possible errors. Lineaments may be used to infer groundwater movement and storage. Lattman and Parizek (1964) were the first to adopt a lineaments map to exploit groundwater. Thereafter, many scholars have applied this approach in complicated geological regions (Solomon and Quiel 2006). Greenbaum (1985), which represents the total length of lineaments in a unit area, as:

$$
L d=\sum_{\frac{i=1}{A}}^{i=n} \mathrm{Li}
$$

Where,

$$
\sum_{i=1}^{i=n} \mathrm{Li}
$$

The 2006 Edition of the Lineaments Map of Nigeria from the Nigerian Geological Survey Agency (N.G.S.A) was digitized and converted to lineament density using the line density tool in spatial analysis tool. This was then classified into four classes viz;- lineament present, not present, neighborhood and linear intersections. Areas with lineament are assigned the maximum rank and without lineament with least. 


\subsection{Drainage}

The drainage-length density is significantly correlated with the groundwater recharge; a zone with a high drainagelength density has a high level of groundwater recharge. Many studies have integrated lineaments and drainage maps to infer the groundwater recharge potential zone (Edet et al. 1998; Shaban et al. 2006).

The Landsat ${ }^{\mathrm{TM}}$ data obtained from EARTH EXPLORER was mosaicked and clipped to the study area. The clipped DEM was then filled, using the fill tool in spatial analysis tool to remove small imperfections in the data. To create a raster of flow direction from each cell to its steepest down slope neighbor flow direction tool was used. A raster of accumulated flow was next created using flow accumulation tool with flow direction as the input and further the drainage density map was obtained by the line density analysis tool.

\subsection{Slope}

Rainfall is the main source of groundwater recharge in tropical and sub-tropical regions. The slope gradient directly influences the infiltration of rainfall. Larger slopes produce a smaller recharge because water runs rapidly off the surface of a steep slope during rainfall, not having sufficient time to infiltrate the surface and recharge the saturated zone.

The slope analysis function in GIS was used to assess the variation of slope in the study area using the Digital Elevation Model (DEM) data from the Landsat ${ }^{\mathrm{TM}}$ data derived from EARTH EXPLORER.

\subsection{Interrelationship between the Factors of the Groundwater Recharge Potential}

There might be interactions between the factors of groundwater recharge. This study used five factors of groundwater recharge potential, namely lithology, land use/cover, lineaments, drainage, and slope. A plot of the interrelationship between these factors is shown in Fig. 3.

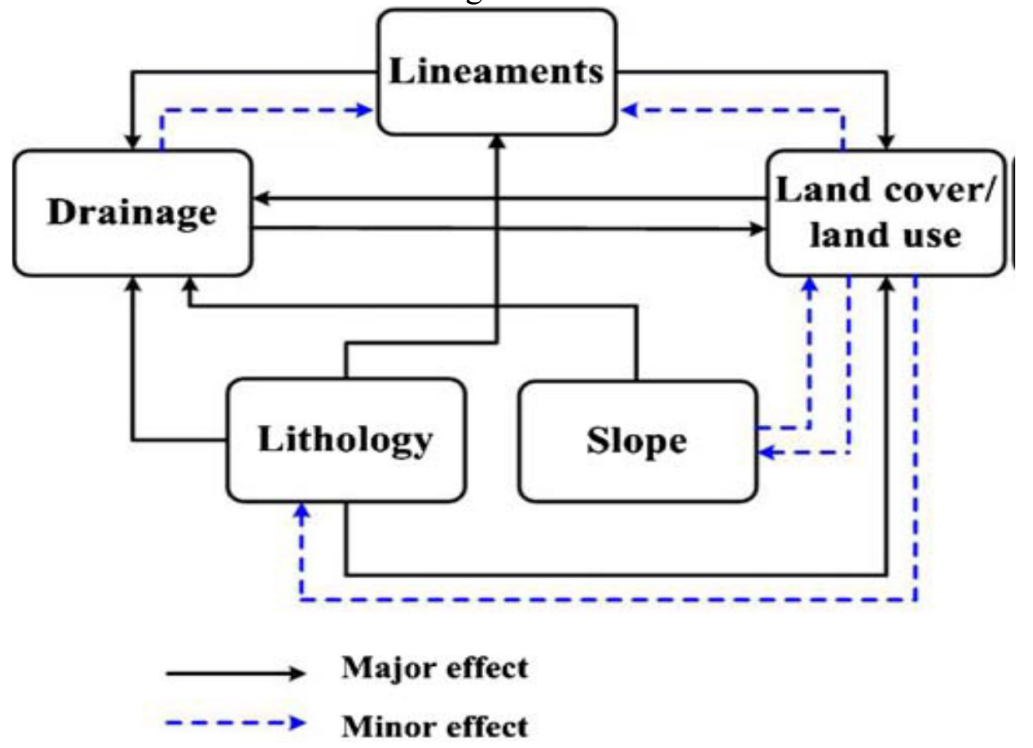

Fig. 3. The interactive influence of factors concerning the recharge potential (modified from Shaban et al. 2006)

Figure 3. illustrates the primary and secondary interrelationships among the factors. Each relationship is weighted according to its onsite relative importance. The representative weight of a factor of the recharge potential is the sum of all weights from each factor. A factor with a higher weight value shows a larger impact on groundwater recharge.

\subsection{Groundwater potential recharge factor weightage}

This study analyzed the hydrologic and geographic attributes of the southern parts of Akwa Ibom State, and identified five factors influencing groundwater recharge potential, namely lithology, land use/cover, lineaments, drainage, and slope. Each factor was examined and was assigned an appropriate weight. Each recharge potential factor may influence the groundwater recharge process to a different degree.

\subsection{Weightage Assignment Criteria}

Weight is used to develop a set of relative weights for a group of factors in a multi-criteria evaluation. The factors influencing groundwater potential recharge like; lithology, slope, land use/land cover, lineament and drainage were examined and assigned appropriate weightage according to the multiple influencing factors (MIF) of that particular feature on the hydrogeological environment of the study area. The effect of each major and minor factor is assigned a weightage of 1.0 and 0.5 respectively. The factors and their resulting weights were used as input for the Weighted 
Overlay Analysis in ArcGIS environment for overlaying of thematic maps.

Moreover, the factors are interdependent. Figure 3. illustrates the conceptual graph of the interrelationships among the groundwater recharge potential factors. Finally, the total weight of each factor is the representing weight of the recharge potential.

For instance, major interrelationships exist for lithology on lineaments, drainage and, land use/cover. Therefore, its evaluated weight is 3.0. This high weight value means that the factor significantly influences the groundwater recharge. Table 2 shows the process for determining the relative rates of each factor.

Table 2. Relative rates for each factor

\begin{tabular}{|l|l|l|}
\hline Factor & Calculation process & Proposed relative rates \\
\hline Lithology & $3 \times 1.0=3.0$ & 3.0 \\
Land cover/ Land use & $1 \times 1.0+3 \times 0.5=2.5$ & 2.5 \\
Lineament & $2 \times 1.0=2.0$ & 2.0 \\
Drainage & $1 \times 1.0+1 \times 0.5=1.5$ & 1.5 \\
Slope & $1 \times 1.0+1 \times 0.5=1.5$ & 1.5 \\
& & $\Sigma 10.5$ \\
\hline
\end{tabular}

The extent of the influence of every factor on groundwater recharge was assessed from the interrelationships among the factors (major and minor). Analytical results demonstrate that the factors influencing the groundwater recharge potential of the southern part of Akwa Ibom State, in descending order, are lithology, land use/cover, lineaments, drainage, and slope. Lithology and land use/cover are the major factors influencing the basin groundwater recharge potential. The score of each recharge potential factor was calculated as 100 multiplied by the weight of the recharge potential divided by the total weight of each recharge potential factor. Table 3 . shows the calculation approach.

Table 3. Score of each recharge potential factor

\begin{tabular}{|l|l|l|}
\hline Factor & Calculation process & Proposed score of each influencing factor \\
\hline Lithology & $100 \times(3 / 10.5)=29$ & 29 \\
Land cover/land use & $100 \times(2.5 / 10.5)=24$ & 24 \\
Lineaments & $100 \times(2 / 10.5)=19$ & 19 \\
& $100 \times(1.5 / 10.5)=14$ & 14 \\
Drainage & $100 \times(1.5 / 10.5)=14$ & 14 \\
Slope & & B 14 \\
& & $\Sigma 100$ \\
\hline
\end{tabular}

A $1 \mathrm{~km} \times 1 \mathrm{~km}$ grid was used to quantify the score of each recharge potential factor based on the characteristics of lithology, land use/cover, lineament-length density, drainage-length density, and slope of the southern part of Akwa Ibom State. The upper threshold of the score of each recharge potential factor was set to be the score of the corresponding recharge potential factor. For example, the highest value of lithology was 29.

\subsection{Data integration and analysis in GIS environment}

After assigning weight, the integration of all layers was carried out applying weighted overlay analysis in a GIS environment (ArcMap 10.5). The output map of the weighted overlay analysis gives the groundwater prospect map of the study area as illustrated in Fig 4. 

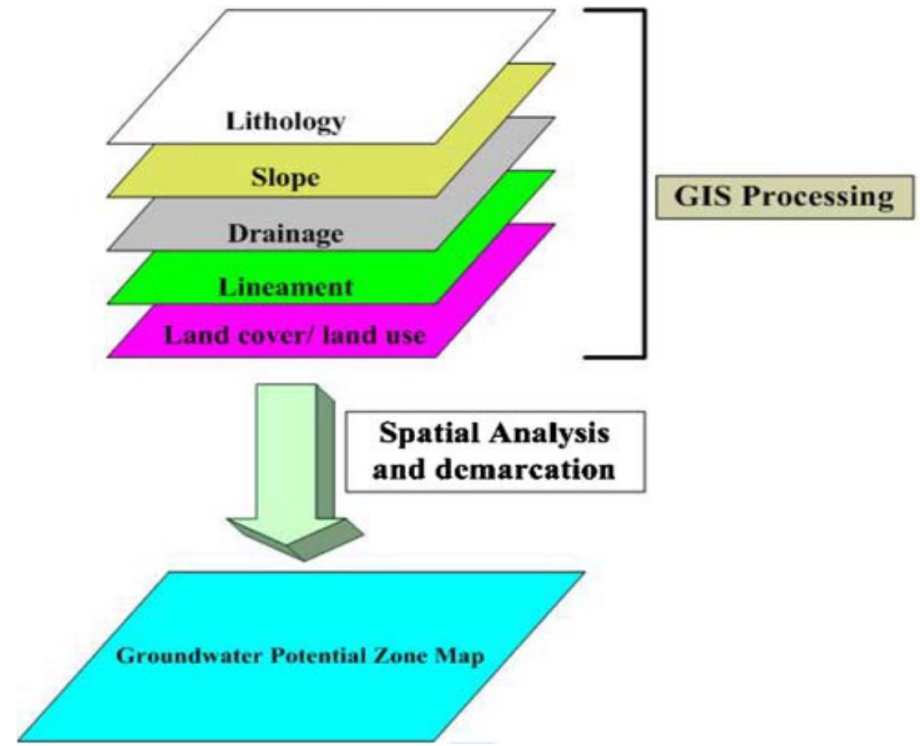

Fig. 4. GIS technology used in spatial integration and analysis to demarcate basin groundwater recharge potential zone.

\section{RESULTS}

\subsection{Thematic maps slope}

The slope gradient in the area varies from 0 to $60^{\circ}$. Areas having slope of $0-20^{\circ}$ slope falls under 'very high' category because of the nearly flat terrain and relatively high infiltration rate. The areas with 20 to $40^{\circ}$ slope are considered as 'high' for groundwater recharge due to slightly undulating topography with some runoff. Most of the study area falls under 0 to $20^{\circ}$ category. The areas having a slope $>40^{\circ}$ cause relatively high runoff and low infiltration, and hence are categorized as 'low'. The distribution of slope classes with respect to recharge potential is shown in Figure 4.

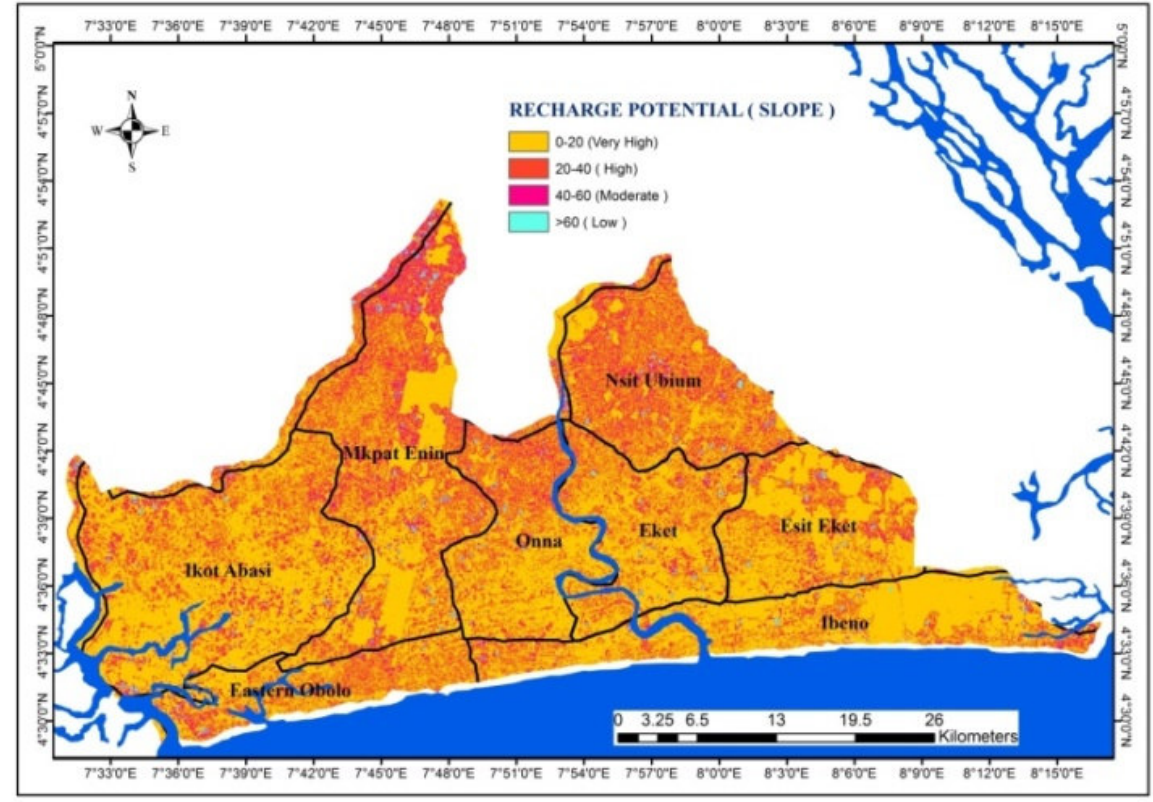

Figure 4. Slope map of the study area.

\subsection{Lineament density $\left(\mathrm{km} / \mathrm{km}^{2}\right)$}

The lineament trends in the study area are predominantly along South-East, North-West and South-West. Groundwater potential is high near lineament intersection zones. Lineament density is divided into four classes based on recharge potential; they are very high i.e. zones of intersection, high i.e. nearest to the zone of lineament intersection, moderate i.e. lineament present but not close to intersections and low i.e. not present as shown in Figure 5. The North-Western part has very high groundwater recharge potential as the lineaments in numbers are concentrated in this region. 


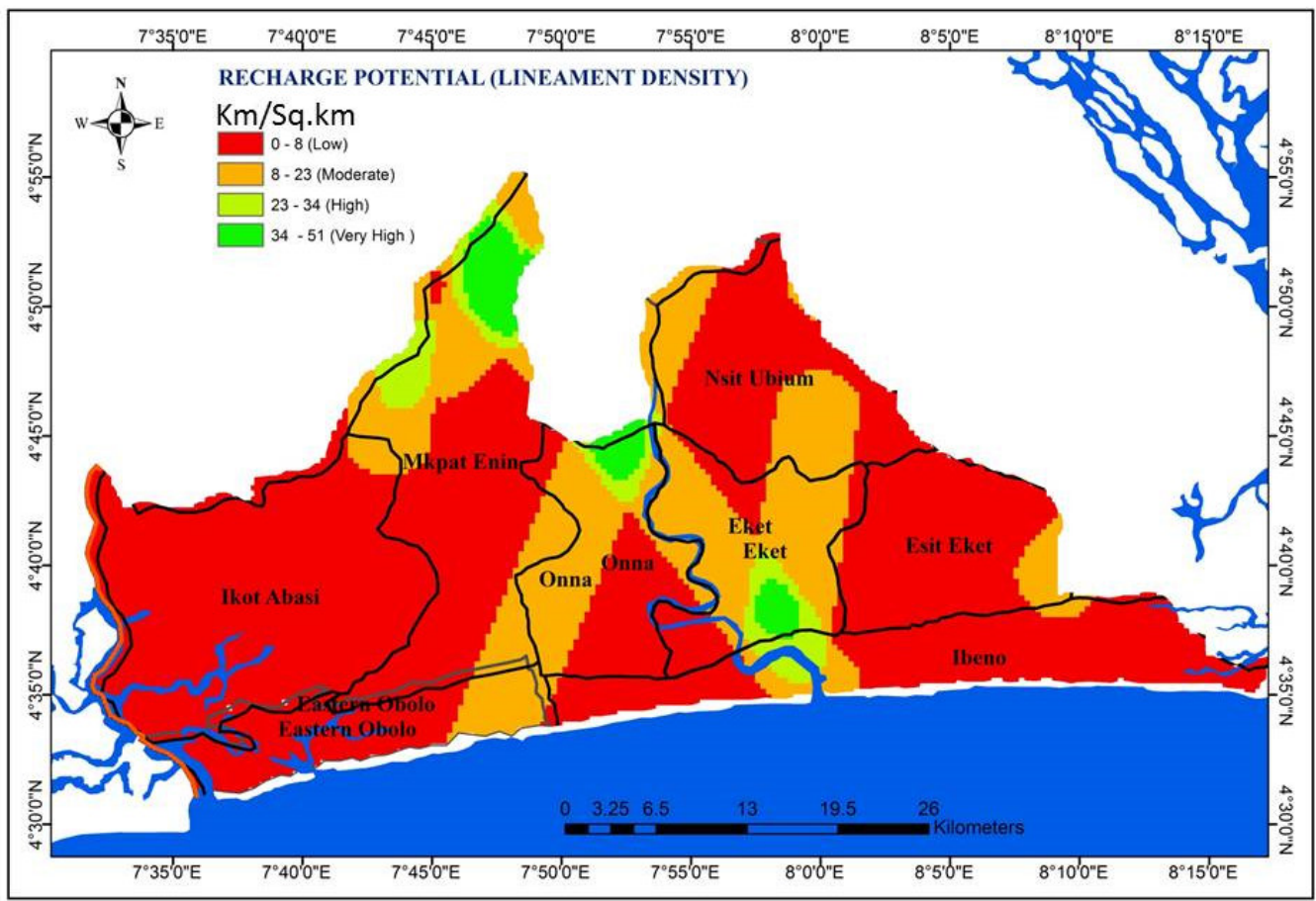

Figure 5. Lineament density map of the study area

\subsection{Analysis of drainage density $\left(\mathrm{km} / \mathrm{km}^{2}\right)$}

The drainage density map reveals a density value ranging from 26 to $244 \mathrm{~km} / \mathrm{km}^{2}$. For analysis purpose, they were regrouped into four categories viz., 26-96, 96-137, 137-176 and 176-244 km/ $\mathrm{km}^{2}$. Considering from a recharge point of view, more weightage is assigned to very low drainage density regions, whereas low weightage is assigned to very high drainage density. As per groundwater recharge potential drainage density is classified into four classes' viz., very high, high, moderate and low (Figure 6).

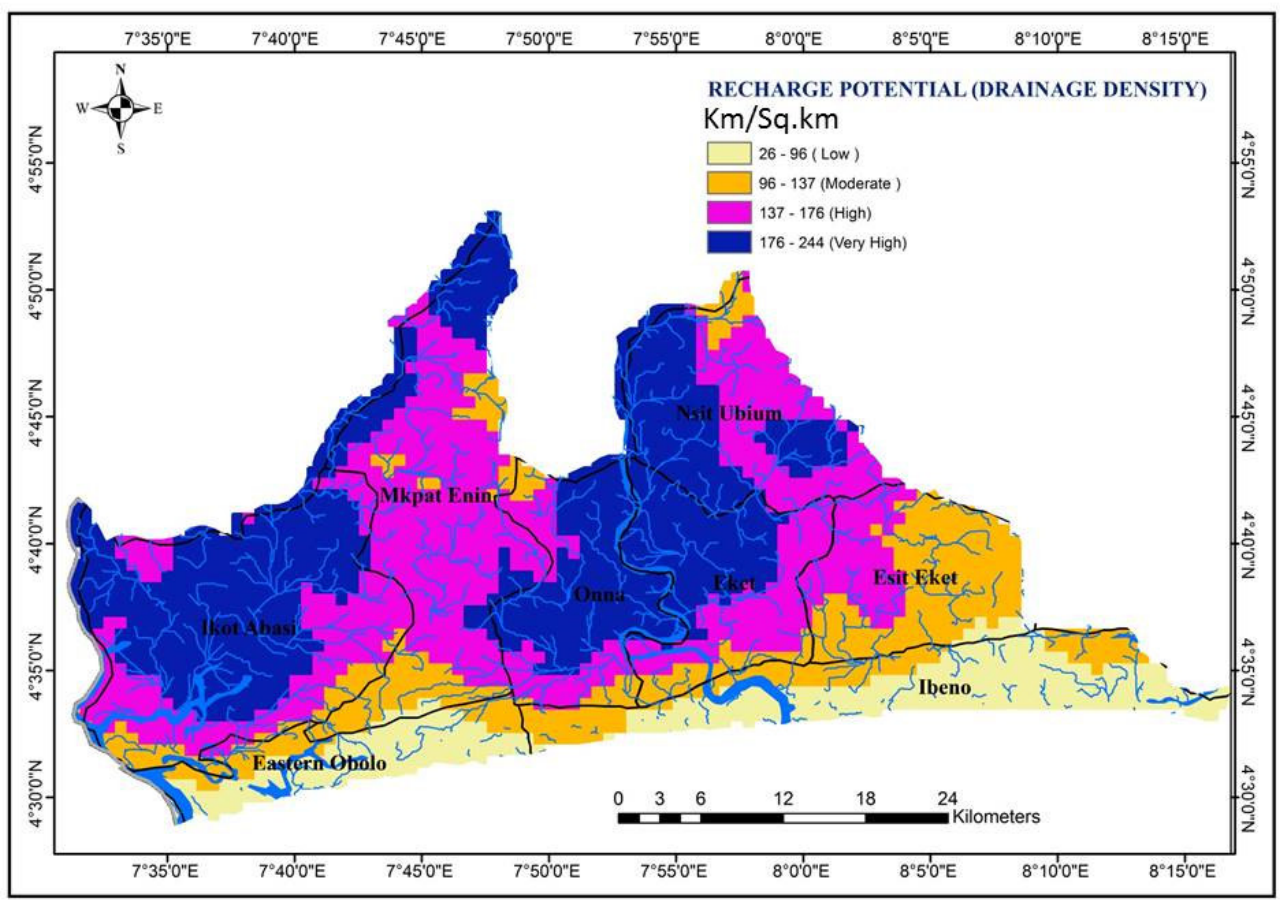

Figure 6. Drainage density map of the study area 


\subsection{Analysis of land use and land cover}

The land use pattern of the study area and various land cover classes were: farm lands, built-up areas, open water and mangrove forest. The land use map with respect to recharge potential is shown in Figure 7. Land use plays a vital role in groundwater prospecting. The rate of infiltration is directly proportional to the density of vegetation cover, i.e., if the surface is covered by dense forest, the infiltration will be more and the runoff will be less. Water bodies are continuous and excellent source of recharge to ground water. Forests, water bodies and crop land were assigned highest rank for groundwater recharge. Built up area have no groundwater recharge potential.

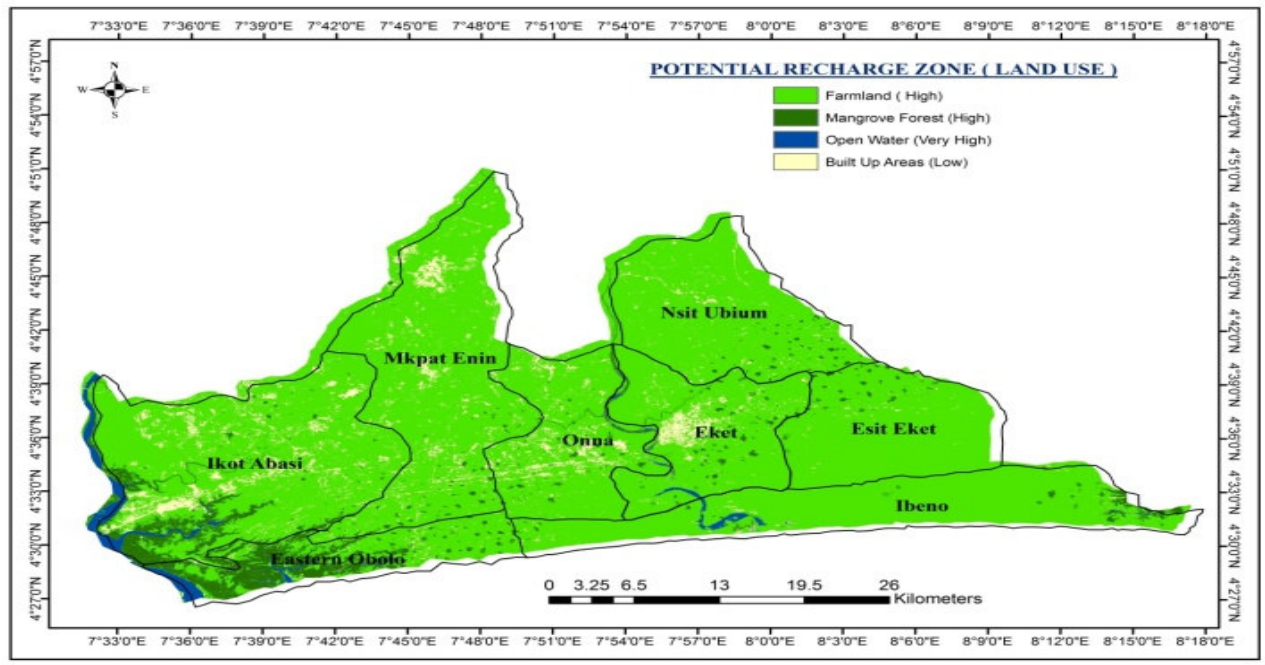

Figure 7. Land use/land cover map of the study area

\subsection{Analysis of Lithology}

The geological map of the study area reveals that the upstream region consists of the Pleistocene coastal plain sands of the Benin Formation. Within the coastal plain sands we have; Unconsolidated sand, gravely sand and clayey intercalations. Additionally the geological map of the study area reveals that the downstream region consists of the Recent Alluvium Ridges which occur mainly in a strip of about $8 \mathrm{~km}$ wide between the mouths of the Imo River, Qua Iboe and Cross Rivers. Within the Alluvium Ridges we have; Gravel, lateritic sand, fine to mediumgrained carbonaceous deposits.

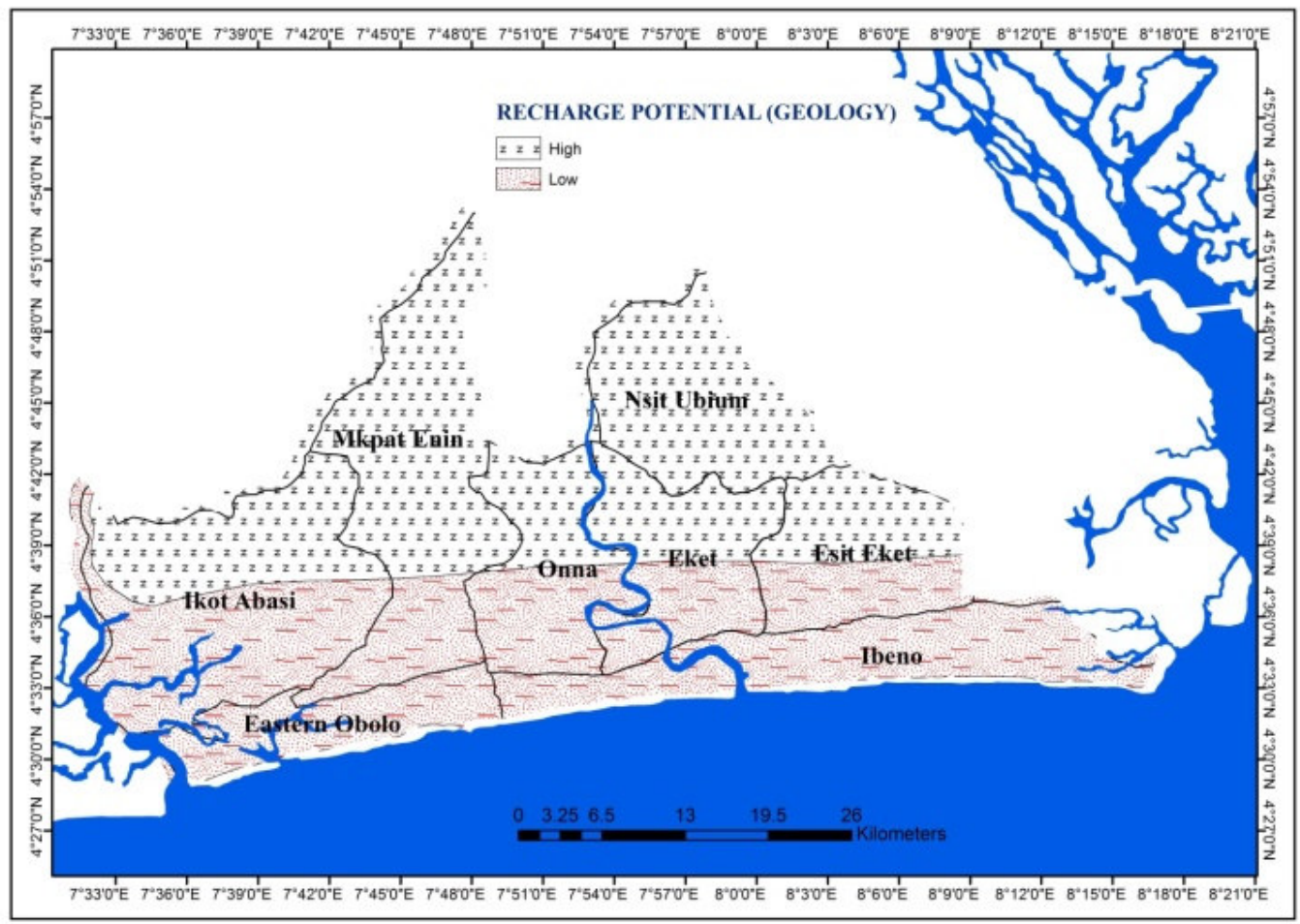

Figure 8 . Lithology map of the study area. 


\subsection{Weightage derivation}

The multi influencing factors for groundwater recharge zones namely geology, slope, land-use/land-cover, drainage density, and lineament density were examined and assigned an appropriate weight and are shown in Table 1. The effect of each influencing factor contributed to the delineating of the groundwater potential zones. Moreover, the factors were interdependent. The effect of each major and minor factor is assigned a weightage of 1.0 and 0.5 respectively. The cumulative weightage of both major and minor effects are considered for calculating the relative rates. This rate is further used to calculate the score of each influencing factor. The proposed score for each influencing factor is calculated by using the formula:

$$
\left[\frac{A+B}{\sum(A+B)}\right] \times 100
$$

Where, $\mathrm{A}$ is major interrelationship between two factors and $\mathrm{B}$ is minor interrelationship between two factors. Classes of each influencing factors were then assigned ranks with respect to its groundwater recharge potential as shown in Table 4.

Table 4. Categorization of factors influencing recharge potential in the study area

\begin{tabular}{|l|l|l|}
\hline Factor & Domain of effect & Proposed weight of effect \\
\hline \multirow{5}{*}{ Slope gradient } & & \\
& $>60^{\circ}$ & 4 \\
& $40-60^{\circ}$ & 7 \\
& $20-40^{\circ}$ & 11 \\
& $0-20^{\circ}$ & 14 \\
& $\left(\mathrm{Km} / \mathrm{km}^{2}\right)$ & \\
& Low & 4 \\
& Moderate & 7 \\
& High & 11 \\
& Very high & 14 \\
& & \\
& $\left(\right.$ Km/km $\left.{ }^{2}\right)$ & \\
& Not present & 6 \\
Lineament density cover/ land use & present & 26 \\
& Built up areas & 6 \\
& Forest & 24 \\
& Agricultural land & 18 \\
& Surface water body or river channel & 12 \\
& & \\
Lithology & Benin formation & 29 \\
& Recent Alluvium & 7 \\
\hline
\end{tabular}

3.6 Integration of thematic layers

All the thematic layers were assigned with the derived weightage values and ranks during weighted overlay analysis in ArcGIS 10.5 software to obtain a unified weight map of the potential groundwater recharge areas. The integrated map indicated the groundwater recharge zones. . Earlier, ranks from 1 to 4 were assigned for individual classes of lithology, slope, land use/ land cover, drainage density and lineament density layers based on the influence on water recharge hence the final output map also possesses 4 classes. Figure 9 shows the groundwater recharge potential diagram of the study area. 


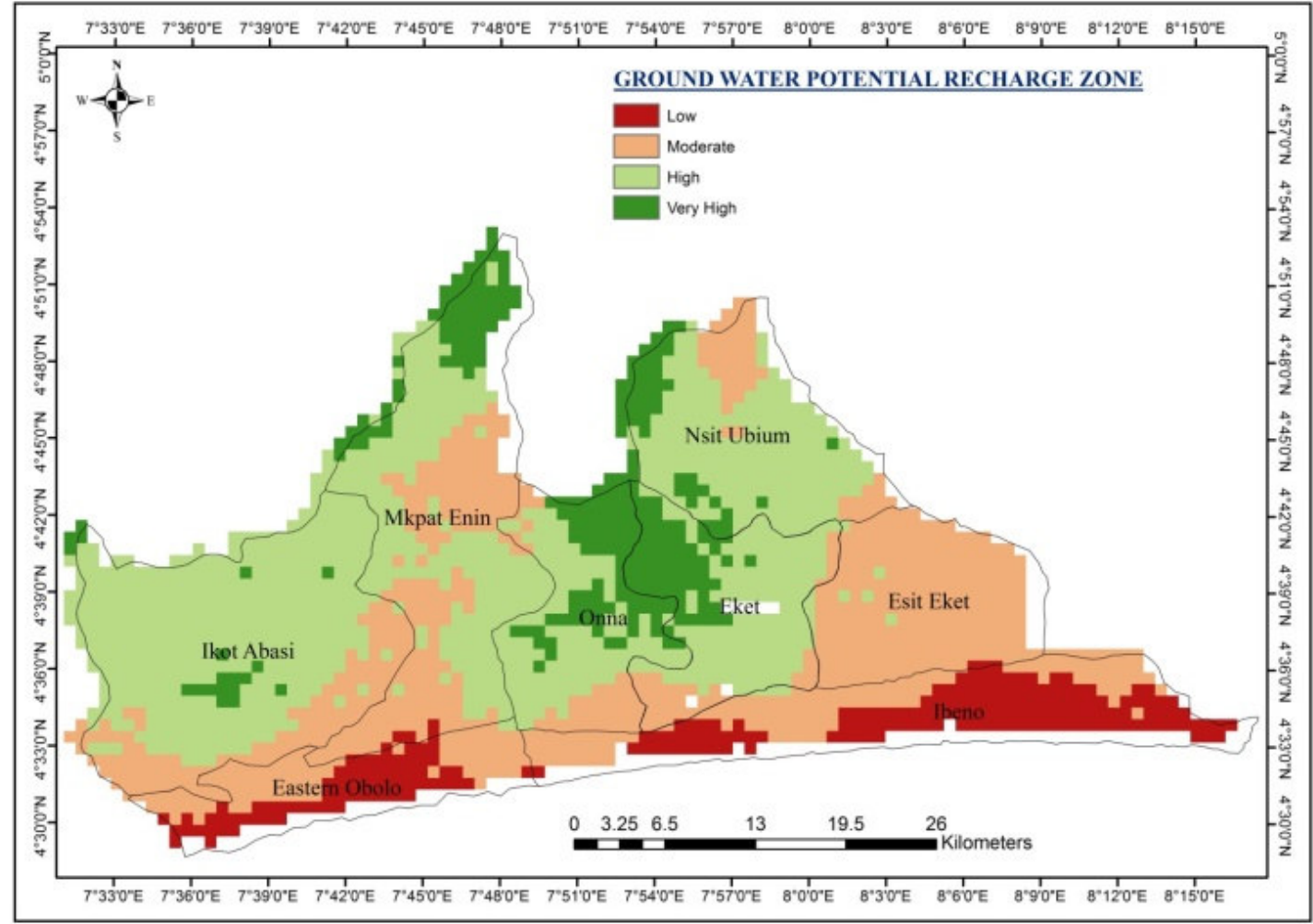

Figure 9. Ground water recharge zoning map of the study area

As per the rank assignment, value 1 indicates very high controlling units, 2 indicates highly controlling units, 3 indicates moderately controlling units and 4 indicates low controlling units.

Similarly, groundwater recharge areas were delineated and classified as follows: value 1 indicates 'very high' or good recharge zones, 2 indicates 'high' recharge, 3 indicates 'moderate' recharge and 4 indicates 'low' recharge areas (Figure 9).

\subsection{DISCUSSION}

Results demonstrate that the groundwater recharge potential zone of this study area can be divided into four grades, namely very high, high, moderate, and low, based on the analysis of the five factors of groundwater recharge potential. Analytical results demonstrate that the excellent groundwater recharge potential zone is concentrated in the up-and mid-stream region due to the distribution of lithology, conjugate lineaments and landuse/landcover with high infiltration ability. Land use/land cover is an important physical factor that affects infiltration, erosion, and evapo-transpiration. Land use plays a vital role in groundwater prospecting. The rate of infiltration is directly proportional to the density of vegetation cover, i.e., if the surface is covered by dense forest, the infiltration will be more and the runoff will be less (Edet et al. 1998). Slope is one of the factors controlling the infiltration of ground water into subsurface; hence an indicator for the suitability for ground water prospect. In a gentle slope area, the surface runoff is slow allowing more time for rain water to percolate, whereas high slope area facilitate high runoff allowing less residence time for rain water hence comparatively less infiltration (Shaban et al 2006). Additionally, the concentration of drainage and slope gradient also helps the stream-flow to recharge the groundwater system. The downstream region is less important and is influenced to an extent by lithology and slope gradient resulting in wetlands especially during the rainy season. Drainage pattern reflects the major characteristics of the surface as well as subsurface formation. The more the drainage density, higher would be the runoff. The suitability of groundwater potential recharge zones is inversely related to drainage density because of its relation with surface runoff and permeability.

\subsection{CONCLUSION}

This study has established the interrelationships between the groundwater recharge potential factors and the groundwater recharge potential scores from the general hydrology characteristics of the southern part of Akwa Ibom State. Since the groundwater recharge potential is directly correlated with percolation, the established scores may be more accurate and objective if the rate of percolation and hydraulic conductivity of each recharge potential factor can be measured in a laboratory or on-site. This study produced a groundwater recharge potential map of parts of Akwa Ibom State. The results indicate that the most effective groundwater recharge potential zone is 
trending in the NW - SE direction. In this region, lineament concentration and intersections are responsible for very high recharge and the coastal plain sands of the Benin Formation, the agricultural land and forest possesses high infiltration ability. Additionally, the concentration of drainage also indicates the ability of stream-flow to recharge the groundwater system. The downstream region is least effective for groundwater recharge, mainly due to its elevation being as low as sea level.

\section{REFERENCES}

Akintola, F.O.1974. The Parameters of Infiltration Equations of Urban Land-Use Surfaces. Unpublished Ph.D Thesis, University of Ibadan

Edet AE, Okereke CS, Teme SC, Esu EO (1998) Application of remote sensing data to groundwater exploration: a case study of the Cross River State, southeastern Nigeria. Hydrogeol J 6:394-404.

El-Baz F, Himida I (1995) Groundwater potential of the Sinai Peninsula. Egypt, Project Summery, AID, Cairo

Freeze RA, Cherry JA (1979) Groundwater. Prentice-Hall, Inc., Englewood Cliffs

Harry, T., Bassey, C., Udofia P., Daniel, S, (2017): Baseline study of Estuarine Oceanographic Effects on Benthic foraminifera in Qua Iboe, Eastern Obolo and Uta Ewa/Opobo River Estuaries, Southeastern Nigeria. Vol. 8. 2017. 1422.

Harry, T.A, Etuk, S. E, Joseph, Okoli Austin (2018) Geomechanical evaluation of reservoirs in the coastal swamp, Niger delta region of Nigeria. 2018, 2018. 6(2): p. 8

Jha, M.; Chowdhury, A.; Chowdary, V. and Peiffer, S. 2007. Groundwater management and development by integrated remote sensing and Geographic Information Systems: Prospects and Constraints. Wat. Res. Manag, 21(2), 427-467

Krasny, J. 1997. Transmissivity and permeability Distribution in Hardrock Environment: A Regional Approach. Pro. Symp. Hard. Rock. Hydrosyst. 52 at Rabat. IAHS Publication. No. 241, 81-90

Lattman LH, Parizek RR (1964) Relationship between fracture traces and the occurrence of groundwater in carbonate rocks. J Hydrol 2:73-91

Leduc C, Favreau G, Schroeter P (2001) Long-term rise in a Sahelian water table: the Continental Terminal in southwest Niger. J Hydrol 243:43-54

Martin, H. (2012). Evaluation of Factors Influencing Transmissivity in Fractured Hard-Rock Aquifers of the Limpopo province. Water SA., 38 (3), 379-390.

Petters, S.W, E.J.; Udo,E.J.; Obot U.W. and Okpon, S.N. (1989). Akwa Ibom State Physical Background, Soils and Land Use Ecological Problems. Technical Report of the Task Force on Soils and Land Use. Govt. Printer Uyo, pp 602.

Salama RB, Tapley I, Ishii T, Hawkes G (1994) Identification of areas of recharge and discharge using LandsatTM satellite imagery and aerial photography mapping techniques. Hydrogeol J 162:119-141

Sander, P. 2007. Lineaments in Groundwater Exploration: A Review of Applications and Limitations. Hydrog. J. Vol. 15(1) Pp 71-74

Sener, E., Davraz, A. and Ozcelik, M. 2005. An Integration of GIS and Remote Sensing in Groundwater Investigations: A Case Study in Burdur, Turkey. Hydrogeology Journal. Vol.13(5). Pp. 826 - 834

Shaban, A.;Khawlie, M. and Abdallah, C. 2006. Use of Remote Sensing and GIS to determine Recharge Potential Zones: the Case of Occidental Lebanon. Hydrog. J., 14(4), 433-443.

Yeh, H. F.; Lee, C. H.; Hsu, K. C. and Chang, P. H. 2008.GIS for the Assessment of the Groundwater Recharge Potential Zone. Env. Geol. DOI: 10.1007/s00254008-1504-9 